\title{
Course of HIV-I infection in a cohort of homosexual and bisexual men: an 11 year follow up study
}

AIDS Office, Department of Public Health, City and County of San Francisco, San Francisco, California 94102, United States George W Rutherford, MD, director

Alan R Lifson, MD, assistant director for research

Nancy A Hessol, MSPH, assistant chief, research branch Paul M O'Malley, project manager, research branch

Susan P Buchbinder, MD, chief, clinical studies section, research branch

J Lowell Barnhart, chief, data management section, research branch

Torsten W Bodecker, research associate, field studies section, research branch Lyn Cannon, project supervisor, research branch

Department of Public Health, City and County of San Francisco

David Werdegar, MD,

director of health

Epidemiology Branch, Division of HIV/AIDS, Center for Infectious

Diseases, Centers for

Disease Control, Atlanta

Georgia 30333 ,

United States

William W Darrow, PHD,

chief, behavioural and social

studies section

Lynda S Doll, PHD, research psychologist, behavioural and social studies section

Scott D Holmberg, MD,

chief, special studies section

Janet S Harrison, MS,

research psychologist,

behavioural and social studies

section

Martha F Rogers, MD, chief

Division of HIV/AIDS,

Center for Infectious

Diseases, Centers for

Disease Control

Harold W Jaffe, MD, deputy

director

Correspondence to: $\mathrm{Dr} \mathrm{G} W$ Rutherford, Infectious

Disease Branch, California

Department of Health

Services, 2151 Berkeley

Way, Room 708, Berkeley,

California 94704, United

States.

BrMed f 1990;301:1183-8

George W Rutherford, Alan R Lifson, Nancy A Hessol, William W Darrow, Paul M O'Malley, Susan P Buchbinder, J Lowell Barnhart, Torsten W Bodecker, Lyn Cannon, Lynda S Doll, Scott D Holmberg, Janet S Harrison, Martha F Rogers, David Werdegar, Harold W Jaffe

Abstract

Objective-To characterise the natural history of sexually transmitted HIV-I infection in homosexual and bisexual men.

Design-Cohort study.

Setting-San Francisco municipal sexually transmitted disease clinic.

Patients-Cohort included 6705 homosexual and bisexual men originally recruited from 1978 to 1980 for studies of sexually transmitted hepatitis B. This analysis is of 489 cohort members who were either HIV-I seropositive on entry into the cohort $(n=312)$ or seroconverted during the study period and had $\leqslant 24$ months between the dates of their last seronegative and first seropositive specimens $(n=177)$. A subset of $\mathbf{4 4 2}$ of these men was examined in 1988 or 1989 or had been reported to have developed AIDS.

Main outcome measures-Development of clinical signs and symptoms of HIV-I infection, including AIDS, AIDS related complex, asymptomatic generalised lymphadenopathy, and no signs or symptoms of infection.

Measurements and main results-Of the 422 men examined in 1988 or 1989 or reported as having AIDS, 341 had been infected from 1977 to $1980 ; 49 \%$ (167) of these men had died of AIDS, $10 \%$ (34) were alive with AIDS, $19 \%(65)$ had AIDS related complex, $3 \%(10)$ had asymptomatic generalised lymphadenopathy, and $19 \%$ (34) had no clinical signs or symptoms of HIV-I infection. Cumulative risk of AIDS by duration of HIV-I infection was analysed for all 489 men by the Kaplan-Meier method. Of these 489 men, $226(46 \%)$ had been diagnosed as having AIDS. We estimated that $13 \%$ of cohort members will have developed AIDS within five years of seroconversion, $51 \%$ within 10 years, and $54 \%$ within $11 \cdot 1$ years.

Conclusion-Our analysis confirming the importance of duration of infection to clinical state and the high risk of AIDS after infection underscores the importance of continuing efforts both to prevent transmission of HIV-I and to develop further treatments to slow or stall the progression of HIV-I infection to AIDS.

\section{Introduction}

The proportion of people infected with HIV-I who will eventually develop life threatening diseases such as AIDS or AIDS related complex is not completely understood. ' Risk of progression from HIV-I infection to AIDS has been prospectively studied in cohorts of homosexual and bisexual men, ${ }^{2-6}$ parenteral drug users, ${ }^{278}$ transfusion recipients, ${ }^{910}$ people with haemophilia, ${ }^{2911-13}$ and vertically infected infants. ${ }^{1416}$ Whereas studies of transfusion recipients, haemophiliac patients, and vertically infected infants have been able to determine the approximate dates of HIV-I seroconversion and therefore the duration of HIV-I infection, studies of sexually transmitted HIV-I infection in homosexual and bisexual men have generally been conducted in men who were already infected with HIV-I at the time of their recruitment. Thus most of these studies have been unable to examine the long term risk of progression from infection to AIDS as a function of duration of HIV-I infection.

To understand better the relation between duration of HIV-I infection and the risk of progressing to AIDS we have expanded our longitudinal cohort study of homosexual and bisexual men. ${ }^{17-21}$ We now report the risk of AIDS in men who have been infected for up to 12 years.

\section{Methods \\ BACKGROUND}

The San Francisco City Clinic cohort was comprised of 6705 men who were recruited from San Francisco City Clinic, the municipal sexually transmitted disease clinic, for studies of the incidence and prevalence of sexually transmitted hepatitis B from 1978 to 1980 . At the time of their recruitment these men were 18 years of age or older and had a history of sexual contact with other men. Details of these original hepatitis B studies have been published previously. ${ }^{2223}$

The first 831 participants were consecutively enrolled from January through May 1978 in a cross sectional study of the prevalence of hepatitis B virus infection. All were interviewed regarding risk factors for this infection. Among the 831 men, 74 (9\%) were negative for seromarkers ( $\mathrm{HBsAg}, \mathrm{HBsAb}, \mathrm{HBcAb}$ ). An additional 5874 men were tested for seromarkers and, if they had no evidence of infection, were asked to participate in a prospective study of the incidence of hepatitis $B$ and to be interviewed and retested at three intervals of four months; $1639(28 \%)$ seronegative men agreed to participate in this incidence study.

In 1980-1 a sample of 359 (21\%) of the participants who were negative for all hepatitis B virus markers in the prevalence $(n=34)$ and incidence $(n=325)$ studies was recruited into a multicenter, randomised double blind trial of plasma derived hepatitis B vaccine; they had serum drawn about every six months. All unused serum samples from the initial screening, the prevalence and incidence studies, and the vaccine trial were frozen and stored.

In 1981 the first cases of Kaposi's sarcoma and Pneumocystis carinii pneumonia were reported in homosexual men. ${ }^{24}$ By $1982,41 \%$ of all reported AIDS cases in San Francisco were among members of the original hepatitis B cohort. Recognising the high incidence of AIDS in the cohort and the similar 
epidemiology of hepatitis B and AIDS, we began epidemiological studies of AIDS in the cohort in 1983. After the identification of HIV-I in 1984, testing for HIV-I antibodies was added to these investigations. By December $1989,75 \%$ of cohort members were infected with HIV-I, and 1479 were reported to have developed AIDS, representing $22 \%$ of all cohort members and $29 \%$ of cohort members infected with HIV-I.

\section{STUDY PARTICIPANTS}

Since October 1983 we have attempted to contact all 6705 cohort members. Each cohort member who agreed to participate in AIDS follow up studies was tested for antibodies to HIV-I and asked for permission to test stored serum samples from the earlier hepatitis studies for HIV-I antibodies. Additionally, serum samples from cohort members who were known to have died before they could be asked to participate in AIDS follow up studies were also tested. Except for cohort members known to have died, no stored serum samples were tested for HIV-I antibody without the written informed consent of the participant. Participants who were consistently negative for HIV-I antibody throughout the study or seropositive for HIV-I on entry into the original cohort in $1978-80$ or who seroconverted to HIV-I during the study with $\leqslant 24$ months between their last negative specimen and their first positive specimen were enrolled in our prospective study of the incidence, prevalence, and course of HIV-I infection. These participants were interviewed regarding behavioural and biological risk factors for HIV-I infection and AIDS, examined by a physician, and tested for antibodies to HIV-I each year or until a diagnosis of AIDS was made.

This analysis includes two groups: all original cohor members who consented to be enrolled in our AIDS follow up studies and who were either positive for HIV-I on entry into the original cohort in $1978-80$ or who seroconverted during the study with $\leqslant 24$ months between the dates of their last specimen negative for antibody to HIV-I and their first positive specimen; and a random sample of cohort members known to have died before they could be asked to participate and who had a similarly well characterised date of seroconversion. This second group was randomly sampled so that the proportion of these deceased cohort members included in this analysis was equal to the proportion of living cohort members in the first group who consented to be enrolled in our AIDS follow up studies. This ensured that deceased cohort members were not disproportionately represented in the analysis.

\section{VARIABLES}

The dependent variable in this study was clinical outcome, including AIDS, AIDS related complex, asymptomatic generalised lymphadenopathy, HIV-I infection with no clinical signs or symptoms, and death. We defined AIDS as the presence of a disease that met the standard 1987 Centers for Disease Control surveillance case definition ${ }^{25}$; AIDS related complex as oral candidiasis or hairy leucoplakia on physical examination or idiopathic fever, diarrhoea, or night sweats of two weeks' duration or longer, or involuntary weight loss of $\geqslant 10$ pounds (not including HIV wasting syndrome) by history; asymptomatic generalised lymphadenopathy as the presence of lymph nodes $\geqslant 1 \mathrm{~cm}$ in diameter at two or more extrainguinal sites, only one of which could be cervical; and no clinical signs or symptoms of HIV-I infection as the absence of AIDS, AIDS related complex, and asymptomatic generalised lymphadenopathy. Clinical outcomes were mutually exclusive, and participants with both AIDS related complex and generalised lymphadenopathy (that is, symptomatic generalised lymphadenopathy) were classified as having AIDS related complex.
AIDS was determined by history and physical examination or by cross matching with San Francisco and national AIDS surveillance registries by date of birth and soundex codes (an alphanumeric code based on last name). Deaths were determined through AIDS surveillance data, by direct report, and through cross matches with San Francisco vital statistics records and the National Death Index. AIDS related complex, asymptomatic generalised lymphadenopathy, and the absence of clinical signs or symptoms of HIV-I infection were determined by history and physical examination. ${ }^{17}$

In addition to cross matching AIDS surveillance registries and death records for participants followed prospectively, we also cross matched these records for all cohort members. We attempted to confirm computer generated matches by contacting the cohort member identified as a possible case or by contacting the source of the report if the participant was known to have died. As described above, participants known to have died before they could be asked to participate in the study had their stored serum samples tested for HIV-I antibody, and a random sample of these men who were seropositive on entry into the cohort or seroconverted after entry with $\leqslant 24$ months between the dates of their last seronegative and first seropositive specimens was included in this analysis.

The principal independent variable in this report is the estimated duration of HIV-I infection after seroconversion to HIV-I. We defined duration of HIV-I infection for men who had not developed AIDS as the length of time from the estimated date of seroconversion to December 1989. For men who had developed AIDS we defined duration of HIV-I infection as the length of time from estimated date of seroconversion to date of diagnosis of AIDS.

For men who seroconverted after entry into the cohort we defined the estimated date of seroconversion as the midpoint between the dates of their last negative and first positive specimen. For men who were seropositive on entry into the cohort we back estimated the date of seroconversion by using a probability estimate based on men with $\leqslant 24$ months between dates of serum specimens. ${ }^{17}$

\section{LABORATORY ANALYSIS}

Serum from both stored and current samples was tested for antibody to HIV-I by enzyme immunosorbent assay. All positive results were confirmed by immunofluorescent assay ${ }^{26}$; if this assay was indeterminate the specimens were also evaluated by western blot assay. ${ }^{27}$ All stored serum samples positive on enzyme immunosorbent assay were confirmed by western blotting; specimens that were indeterminate by western blotting were then evaluated with a recombinant immunoblot assay (Chiron Corporation, Emeryville, California). For seropositive participants complete blood counts and analyses of $\mathrm{T}$ cell subsets were performed.

\section{ANALYTIC METHODS}

For men with well characterised dates of seroconversion who had either developed AIDS or who had been examined by us in 1988 or 1989 we examined clinical outcomes cross sectionally by estimated year of seroconversion. We estimated the cumulative risk of AIDS by duration of HIV-I infection for all men with well characterised dates of seroconversion by using the Kaplan-Meier time to progression method..$^{28} 29$

To evaluate the influence of zidovudine on cumulative risk of progression to AIDS we performed stratified Kaplan-Meier analysis on three subgroups of men with well characterised dates of seroconversion: men diagnosed as having AIDS before the licensing of zidovudine in September 1987; men interviewed after September 1987 who reported a history of zidovudine 
TABLE I - Participation rates and AIDS rate in San Francisco City Clinic cohort

\begin{tabular}{lccccc}
\hline & \multicolumn{2}{c}{ Enrolled in AIDS studies } & & \multicolumn{2}{c}{ Not enrolled in AIDS studies } \\
\cline { 2 - 3 } \cline { 5 - 6 } & No $(\%)$ & AIDS rate & & No $(\%)$ & AIDS rate \\
\hline Hepatitis B virus studies: & $2877(43)$ & $21 \cdot 2$ & & $3828(57)$ & $22 \cdot 6$ \\
Prevalence study & $503(61)$ & 27.6 & & $328(39)$ & $22 \cdot 8$ \\
Incidence study: & $1644(39)$ & $22 \cdot 3$ & & $2591(61)$ & 26.0 \\
$\quad$ Screened $t$ & $730(45)$ & $14 \cdot 2$ & & $909(55)$ & $12 \cdot 9$ \\
Participated $\ddagger$ & $309(86)$ & 13.9 & & $50(14)$ & $12 \cdot 0$ \\
HBV Vaccine Trial $\$$ & & & &
\end{tabular}

${ }^{\star}$ Cumulative AIDS cases per 100 participants.

†Positive for any marker of hepatitis B virus infection ( $\mathrm{HBsAg}, \mathrm{HBsAb}, \mathrm{HBcAb}$ ) on entry into study. $\ddagger$ Negative for markers on entry into study.

$\$ 34$ Participants from the prevalence study and 325 from the incidence study were enrolled in the vaccine trial.

TABLE II - Estimated year of $H I V-I$ seroconversion in $S a n$ Francisco City Clinic cohort. Values are numbers (percentages)

\begin{tabular}{lcc}
\hline $\begin{array}{l}\text { Estimated } \\
\text { year of } \\
\text { seroconversion }\end{array}$ & \multicolumn{2}{l}{ Annual Cumulative } \\
\hline 1977 & $3(1)$ & $3(1)$ \\
1978 & $114(23)$ & $117(24)$ \\
1979 & $143(29)$ & $260(53)$ \\
1980 & $121(25)$ & $381(78)$ \\
1981 & $42(9)$ & $423(86)$ \\
1982 & $30(6)$ & $453(93)$ \\
1983 & $7(1)$ & $460(94)$ \\
1984 & $9(2)$ & $469(96)$ \\
1985 & $4(1)$ & $473(97)$ \\
1986 & $5(1)$ & $478(98)$ \\
1987 & $3(1)$ & $481(98)$ \\
1988 & $4(1)$ & $485(99)$ \\
1989 & $4(1)$ & $489(100)$ \\
\hline
\end{tabular}

use of at least two months' duration either before a diagnosis of AIDS or, if not diagnosed as having AIDS, at the time of their last clinical evaluation; and men interviewed after September 1987 who reported no use of zidovudine either before a diagnosis of AIDS or, if not diagnosed as having AIDS, at the time of their last clinical evaluation. We excluded men who had not been interviewed since September 1987 from this analysis.

\section{Results}

Of the 6705 original cohort members, 4043 (60\%) were living when they were asked to participate in AIDS follow up studies, $699(10 \%)$ were known to have died before they could be asked to participate, and 1963 (29\%) were lost to follow up. Of the 4043 participants alive at the time of contact, 2877 (71\%) consented to have their stored serum samples tested for HIV-I antibodies. Stored samples were also tested for $675(97 \%)$ of the participants known to have died before they could be asked to participate in AIDS studies. Overall, $61 \%$ of participants from the hepatitis B virus prevalence study, $45 \%$ of participants from the incidence study, and $86 \%$ of participants from the vaccine trial were enrolled in our AIDS follow up studies. The enrolment rate was higher for men who participated in the hepatitis B vaccine trial than for men who participated in the prevalence study and the incidence study. The cumulative rate of AIDS was $21 \cdot 2 \%$ among men enrolled in AIDS studies and $22 \cdot 6 \%$ among men not enrolled $(\mathrm{p}=0 \cdot 17$, table I).

Of the 2877 men who entered our AIDS follow up studies, $223(8 \%)$ were HIV-I seropositive on entry into the cohort between 1978 and $1980,165(6 \%)$ seroconverted with $\leqslant 24$ months between the dates of their last seronegative and first seropositive specimens, $1058(37 \%)$ seroconverted with $\geqslant 25$ months between the dates of their last seronegative and first seropositive specimen, and $1431(50 \%)$ were seronegative on analysis of their last specimen. Of the 675 men tested who died before they could be asked to participate, $130(19 \%)$ were seropositive on entry, $13(2 \%)$ seroconverted with $\leqslant 24$ months between the dates of their last seronegative and first seropositive specimens, 10 $(1 \%)$ seroconverted with $\geqslant 25$ months between the dates of their last seronegative and first seropositive specimen, and $522(77 \%)$ were seronegative on the date of their last specimen. Of the 143 men with well characterised dates of seroconversion who died before they could be asked to participate, $101(71 \%)$ were selected for inclusion in the analysis.

TABLE III-Clinical outcome by estimated year of seroconversion, San Francisco Clinic cohort

\begin{tabular}{|c|c|c|c|c|c|}
\hline \multirow{2}{*}{$\begin{array}{l}\text { Year of } \\
\text { seroconversion }\end{array}$} & \multicolumn{2}{|c|}{ No $(\%)$ with AIDS } & \multirow{2}{*}{$\begin{array}{l}\text { No (\%) with AIDS } \\
\text { related complex }\end{array}$} & \multirow{2}{*}{$\begin{array}{c}\text { No (\%) with } \\
\text { asymptomatic } \\
\text { generalised } \\
\text { lymphadenopathy }\end{array}$} & \multirow{2}{*}{$\begin{array}{l}\text { No }(\%) \text { with no signs } \\
\text { or symptoms }\end{array}$} \\
\hline & Died & Alive & & & \\
\hline $1977-80(n=341)$ & $168(49)$ & $34(10)$ & $64(19)$ & $9(3)$ & $66(19)$ \\
\hline $1981-3(n=73)$ & $19(26)$ & $8(11)$ & $16(22)$ & $6(8)$ & $24(33)$ \\
\hline $1984-6(n=17)$ & $2(12)$ & $2(12)$ & $4(23)$ & & $9(53)$ \\
\hline $1987-9(n=11)$ & & & & $2(18)$ & $9(82)$ \\
\hline
\end{tabular}

Overall, 489 men were included in this analysis, 312 $(64 \%)$ of whom were seropositive on entry and 177 (36\%) of whom seroconverted with $\leqslant 24$ months between the dates of their last seronegative and first seropositive specimens. Of these 489 men, 381 (28\%) were estimated to have seroconverted before 1981 and $469(96 \%)$ were estimated to have seroconverted before 1985 (table II).

Of these 489 men, $442(90 \%)$ had been examined by us in 1988 or 1989 or had developed AIDS. Table III shows the number of men who died of AIDS, were alive with AIDS, had AIDS related complex, had asymptomatic generalised lymphadenopathy, and had no clinical signs and symptoms of HIV-I infection according to the years during which they were infected with HIV-I. Of the 75 participants who had either asymptomatic generalised lymphadenopathy or no signs or symptoms of HIV infection in December 1989 and had been infected in 1977-80, 39 $(52 \%)$ had $\geqslant 500$ CD4+ cells $/ \mathrm{mm}^{3}, 31(41 \%)$ had $200-499 \mathrm{CD} 4+$ cells/ $\mathrm{mm}^{3}$, and $5(7 \%)$ had $<200 \mathrm{CD} 4+$ cells $/ \mathrm{mm}^{3}$.

These data can also be expressed as the ratios of the cumulative number of participants with AIDS (dead and alive), AIDS related complex, and asymptomatic generalised lymphadenopathy or no clinical signs or symptoms of infection. These ratios vary with duration of illness with approximately 1.0 AIDS cases for every 0.7 participants without AIDS among those infected for $10-12$ years to 1.0 AIDS cases for every 3.2 participants without AIDS among those infected for 4-6 years (table IV).

TABLE IV-Ratio between clinical outcomes by duration of HIV-I infection, San Francisco City Clinic cohort. Includes 442 men who were clinically evaluated in 1988-1989 or known to have developed AIDS

\begin{tabular}{lrccc}
\hline $\begin{array}{l}\text { Year of } \\
\text { seroconversion }\end{array}$ & No & AIDS & $\begin{array}{c}\text { AIDS related } \\
\text { complex }(95 \% \mathrm{CI})\end{array}$ & $\begin{array}{c}\text { AGL and NSS } \\
(95 \% \mathrm{CI})\end{array}$ \\
\hline $1977-80$ & 341 & $1 \cdot 0$ & $0 \cdot 3(0 \cdot 2$ to $0 \cdot 4)$ & $0 \cdot 4(0 \cdot 3$ to $0 \cdot 5)$ \\
$1981-3$ & 73 & $1 \cdot 0$ & $0 \cdot 6(0 \cdot 3$ to $1 \cdot 0)$ & $1 \cdot 1(0 \cdot 7$ to $1 \cdot 7)$ \\
$1984-6$ & 17 & $1 \cdot 0$ & $1 \cdot 0(0 \cdot 3$ to $3 \cdot 4)$ & $2 \cdot 2(0 \cdot 8$ to $5 \cdot 9)$ \\
$1987-9$ & 11 & 0 & &
\end{tabular}

$\mathrm{AGL}=$ asymptomatic generalised lymphadenopathy; NSS = no clinical signs or symptoms of HIV-I infection; $95 \% \mathrm{CI}=95 \%$ confidence interval by Taylor series analysis.

To further define the relation between duration of HIV-I infection and disease progression we included data from all 489 men with well characterised dates of seroconversion in a Kaplan-Meier curve of the cumulative proportion of men with AIDS by estimated duration of infection. Of these 489 men, 226 (46\%) had been diagnosed as having AIDS. Table $\mathrm{V}$ shows the cumulative risk of AIDS since seroconversion. No AIDS cases have as yet been reported among the 40 (8\%) participants infected for more than $11 \cdot 1$ (range $11 \cdot 1$ to $12 \cdot 0)$ years. Of these 40 participants, $24(60 \%)$ had been examined by us in 1988 or 1989 . Of these 24 , $13(54 \%)$ had AIDS related complex, one (4\%) had asymptomatic generalised lymphadenopathy, and 10 $(42 \%)$ had no signs or symptoms of HIV-I infection. Seven $(29 \%)$ of the 24 had $<200 \mathrm{CD} 4+$ cells $/ \mathrm{mm}^{3}$, seven (29\%) had 200-499 CD4+ cells $/ \mathrm{mm}^{3}$, and 10 $(42 \%)$ had $\geqslant 500 \mathrm{CD} 4+$ cells $/ \mathrm{mm}^{3}$. Overall, seven ( $29 \%$ ) of these 24 men had both $\geqslant 500 \mathrm{CD} 4+$ cells $/ \mathrm{mm}^{3}$ and no clinical signs or symptoms of HIV-I infection.

Cumulative risk of progression to AIDS by estimated duration of infection among participants originally recruited from the hepatitis B virus prevalence study, incidence study, and vaccine trial did not differ significantly, nor did the cumulative risk of progression between men seropositive on entry into the cohort and those who seroconverted during the study. Cumulative risk of progression to AIDS among the 173 men with well characterised date of seroconversion who were interviewed and diagnosed as having AIDS after September 1987 (to whom zidovudine was available) 
TABLE V-Cumulative risk of AIDS by time since HIV-I seroconversion, San Francisco Clinic cohort

Percentage $(95 \%$ confidence

\begin{tabular}{|c|c|}
\hline $\begin{array}{l}\text { Years since } \\
\text { seroconversion }\end{array}$ & $\begin{array}{c}\text { Percentage (95\% } \\
\text { confidence } \\
\text { interval) } \\
\text { developing AIDS } \\
(\mathrm{n}=226)\end{array}$ \\
\hline 1 & 0 \\
\hline 2 & $l(0$ to 2$)$ \\
\hline 3 & $3(1$ to 5$)$ \\
\hline 4 & $8(6$ to 10$)$ \\
\hline 5 & 13 (10 to 16$)$ \\
\hline 6 & 20 (16 to 24$)$ \\
\hline 7 & $28(24$ to 32$)$ \\
\hline 8 & $37(33$ to 41$)$ \\
\hline 9 & $44(39$ to 49$)$ \\
\hline 10 & 51 (46 to 56$)$ \\
\hline 11 & $54(49$ to 59$)$ \\
\hline
\end{tabular}
diagnosed as having AIDS during or before September 1987 (to whom zidovudine was not available). Among the 173 men diagnosed after September 1987, however, there was no difference in risk of progression between those who did $(n=38)$ and did not $(n=135)$ report taking zidovudine. Men who did report zidovudine use were more likely to have symptoms (79\%) than men who did not $(21 \%)$, possibly contributing to the lack of difference in risk of AIDS between these groups.

\section{Discussion}

Of the men in this study whom we estimated to have seroconverted to HIV-I from 1977 to $1980,81 \%$ had signs or symptoms of HIV-I infection or had died of AIDS. Over time, there has been a gradual decline in the proportion of infected men who remain clinically well and an increase in the proportion with AIDS and other clinical manifestations of HIV-I infection. Among men who have developed AIDS, our analysis shows that the likelihood of developing AIDS is directly related to the duration of HIV-I infection. This risk increases over time, with an estimated cumulative incidence of AIDS of $54 \%$ (49\% to 59\%) 11 years after seroconversion.

There are, however, at least five potential sources of systematic error in this study. Firstly, cohort members were originally recruited from a sexually transmitted disease clinic, and if repeated venereal infections or reexposure to HIV-I are important in the development of AIDS and the other clinical manifestations of HIV-I infection, ${ }^{30-34}$ these men may be at higher risk of clinical disease than a randomly selected population of homosexual and bisexual men infected with HIV-I. This would limit the populations to which our results should be generalised. For example, some laboratory studies have suggested that coinfection with cytomegalovirus or herpes simplex virus enhances HIV-I replication. ${ }^{3031}$ Arguing against this is our finding that the cumulative risk of AIDS among men who participated in our hepatitis B virus trials and who had therefore never been infected with hepatitis $B$, a sexually transmitted disease of homosexual and bisexual men, did not differ from the risk for other men in the cohort $(72 \%$ of whom had markers of previous or current hepatitis B infection at the time of recruitment) Additionally, our cumulative risk of AIDS by estimated duration of HIV-I infection is lower than that reported from other seroincident cohorts of homosexual and bisexual men infected with HIV-I. For example, the risk of AIDS was $9.6 \%$ after 30 months in an Amsterdam cohort of homosexual and bisexual men. ${ }^{6}$ Similarly, the five year risk of AIDS was estimated to be $22 \%$ ( $16 \%$ to $25 \%$ ) in the multicenter AIDS collaborative study ${ }^{4}$ and $23 \%(22 \%$ to $24 \%)$ in the National Cancer Institute registry of homosexual male HIV-I seroconverters ${ }^{3}$ (R J Biggar, personal communication). In our cohort, the corresponding observed risks of AIDS were $3 \%$ $(1 \%$ to $5 \%)$ three years after seroconversion and $13 \%$ $(10 \%$ to $16 \%)$ five years after seroconversion.

Secondly, a variety of other biological and behavioural factors have been proposed that may be associated with increased risk of clinical disease or immunological deterioration among people already infected with HIV-I. ${ }^{136}$ These include age ${ }^{13}{ }^{37}$ cigarette smoking, ${ }^{38}{ }^{39}$ gender, ${ }^{34}$ continued intravenous drug use, ${ }^{40}$ pregnancy, ${ }^{41+2}$ psychosocial factors, ${ }^{43}$ and host genetic factors. ${ }^{4+4}$ Beyond comparing participants in the hepatitis $B$ vaccine trial with other members of the cohort our analysis does not include potential cofactors, so the disproportionate presence of cofactors in this cohort, as compared with the general homosexual and bisexual male population, might lead to overestimation or underestimation of risk of disease.
A third source of error in this study may be participant bias. Overestimation of the risk of clinical disease may have resulted from disproportionate participation of cohort members who had symptoms and desired further medical evaluation, but, given that the incidence of AIDS was similar among men enrolled and not enrolled in AIDS follow up studies from all three hepatitis studies, there is little objective evidence to support this as a source of systematic overestimation of clinical disease.

Alternatively, risk of disease may have been underestimated as a result of non-participation due to HIV-I related disease or death. We attempted to minimise this bias by cross matching participants with San Francisco and national AIDS and death registries and by including in our analysis a sample of cohort members known to have died before they could be asked to participate in AIDS follow up studies. Additionally, as the incidence of AIDS was similar among participants and non-participants, there is also little objective evidence to support systematic underestimation.

Lastly, our modelling of seroconversion dates of men who were seropositive on entry into the study may have led to overestimation or underestimation of the risk of clinical disease, ${ }^{4}$ but previous analysis of subjects in this cohort who seroconverted suggested that the first seroconversions occurred in $1977 .^{17}$ Additionally, we found no difference in risk of progression between men seropositive on entry and those who seroconverted.

Comparable data for the risk of clinical disease after more than five years of HIV-I infection are not available from other cohorts of homosexual and bisexual men. The cumulative risk of AIDS has been reported to be $49 \%(36 \%$ to $62 \%)$ seven years after HIV-I infection (rather than seroconversion) for transfusion recipients ${ }^{10}$ and $25 \cdot 1 \%(20 \cdot 3 \%$ to $29 \cdot 9 \%)$ nine years after seroconversion for people with haemophilia. ${ }^{13}$ Differences in routes of transmssion, in inoculum sizes, and probably in underlying host immunity may limit the direct comparablility of these types of cohorts to cohorts of homosexual and bisexual men infected through sexual intercourse.

In our analysis we estimated time from seroconversion to diagnosis of AIDS rather than time from HIV-I infection to diagnosis of AIDS. Although most people seem to develop detectable antibody to HIV-I within a few months after infection, there have been reports of people who took six months or more to develop a diagnostic antibody response, suggesting the possibility of HIV-I infection months to years before the appearance of a positive test result. ${ }^{46-48}$ We have previously published studies evaluating specimens negative for HIV-I antibody by using polymerase chain reaction techniques; these studies suggest that this phenomenon, if it occurred, was extremely unusual in this cohort. ${ }^{49-51}$ Models of the time from detecting HIV DNA by the polymerase chain reaction to detecting HIV antibody estimated a median duration of $2 \cdot 4$ months; the time after which $95 \%$ of cases would be predicted to have seroconverted was estimated to be 10.3 months. ${ }^{51}$ Therefore, the possibility of long periods of $\mathrm{HIV}$ infection before seroconversion in our cohort seems very low.

The likelihood of eventually developing AIDS after HIV-I infection remains unknown. The fact that $19 \%$ of subjects in our study who seroconverted from 1977 to 1980 have not developed clinical signs or symptoms of HIV-I infection suggests that AIDS may not be the inevitable consequence of HIV-I infection. More important, however, is developing treatments for those in the earlier stages of HIV-I infection. Although we were unable to show a protective effect for zidovudine in a small non-randomised group of participants in 
our study, zidovudine has been shown in randomised placebo controlled trials to slow progression to clinical disease among certain categories of patients infected with HIV-I. ${ }^{52}$ What impact this and other therapeutic approaches will have on the course of HIV-I infection is not currently known. Our analysis confirming the importance of duration of infection to clinical state and the high risk of AIDS after infection underscores the importance of continuing efforts both to prevent transmission of HIV-I and to develop further treatments to slow or stall the progression of HIV-I infection to AIDS.

We gratefully acknowledge the cooperation of the many men who participated in this study and the help of our colleagues, including Arthur F Back, Carol Badran, Donald Baker (deceased), Fatmata Bangura, Robert H Byers Jr, Jack Campbell (deceased), David Colbert, Ricardo Cottington, Dean F Echenberg, Joseph G Engelman, Aida Flandez, Donald P Francis, Patty Franklin, Douglas R Franks, Michael A Frigo (deceased), Delia Garcia, Steven Gavin (deceased), Shirley Gee, Stephen C Hadler, Ben Heath, Fred R Ingram, Barbara Kilbourne, Robert Kono, Irene Lee, George F Lemp, Carmen Little, Linda Marquis, Richard W Maus, Bobby Martin, Tim Morta, Janet K A Nicholson, Frank Phillips, Michael Piccini, Rebecca Portugal, Phillip Reiff (deceased), Christopher J Rubino, Charles A Schable, Susan Scheer, Terrence Sha, Jose Sion (deceased), Eric Sorenson, Rand L Stoneburner, Johnny Symons, Ron Underwood, Belinda Van, Eric Vittinghoff, Robert Wade, Stephen $\mathrm{H}$ Waterman, Judith Wilber, Thomas E Wilson (deceased) and Laurie Windle. We also thank James W Curran and Stephen B Hulley for reviewing the manuscrip and Judith Sedgwick for typing the manuscript. This study was supported by a cooperative agreement (No U62/CCU900 523-03-5) from the Centers for Disease Control, Atlanta, Georgia. Use of trade names is for identification only and does not imply endorsement by the City and County of San Francisco, the Public Health Service, or the United States Department of Health and Human Services.

1 Lifson AR, Rutherford GW, Jaffe HW. The natural history of human immunodeficiency virus infection. I Infect Dis 1988;158:1360-7.

2 Goeddert JJ, Biggar RJ, Weiss SH, et al. Three-year incidence of AIDS in five cohorts of HTLV-III-infected risk group members. Science 1986;231:992-5.

3 Stevens CE, Taylor PE, Zang EA, et al. Human T-cell lymphotropic virus type III infection in a cohort of homosexual men in New York City. $\mathcal{F} A M A$ 1986:255:2167-72.

4 Munoz A, Wang MC, Bass S, et al. Acquired immunodeficiency syndrome (AIDS)-free time after human immunodeficiency virus type 1 (HIV-I) seroconversion in homosexual men. Am f Epidemiol 1989;130:530-9.

5 Moss AR, Bacchetti P, Osmond D, et al. Seropositivity for HIV and the development of AIDS or AIDS-related conditions: three-year follow-up of the San Francisco General Hospital cohort. BMF 1988;296:745-50.

6 De Wolf F, Lange JMA, Houweling JTM, et al. Appearances of predictors of disease progression in relation to development of AIDS. AIDS 1989;3 563-9.

7 Flegg PJ, Cowan FM, Jones ME, MacCallum LR, Whitelaw JM, Brettle RP. Prospective evaluation of HIV progression in Edinburgh injection drug users [Abstract MAP 105]. In: Abstracts of the fifth international conference on users [Abstract MAP 105$]$. In: Abstracts of the fifth international conference on
AIDS. Montreal, Quebec: International Development Research Centre, AIDS. Montreal, Quebec: International Development Research
Health and Welfare Canada, World Health Organisation, 1989:95.

8 Rezza G, Lazzarin A, Angarano G, et al. The natural history of HIV infection in intravenous drug users: risk of disease progression in a cohort of in intravenous drug users: risk of
seroconverters. AIDS 1989:3:87-90.

9 Giesecke J, Scalia-Tomba G, Berglund O, Berntorp E, Schulman S, Stingenda L. Incidence of symptoms and AIDS in 146 Swedish haemophiliacs and blood transfusion recipients infected with human immunodeficiency virus. BMF 1988;297:99-102.

10 Ward JW, Bush TJ, Perkins HA, et al. The natural history of transfusionassociated HIV infection: factors influencing progression to disease. $N E n g$ J Med 1989;321:947-52.

11 Eyster ME, Gail MH, Ballard JO, Al-Mondhiry H, Goedert JJ. Natural history of human immunodeficiency virus infections in haemophiliacs: effects of T-cell subsets, platelet counts, and age. Ann Intern Med 1987;107:1-6.

12 Jason J, Lui K-J, Ragni MV, Hessol NA, Darrow WW. Risk of developin AIDS in HIV-infected cohorts of hemophilic and homosexual men. $7 A M A$ 1989;261:725-7.

13 Goeddert JJ, Kessler CM, Aledort LM, et al. A prospective study of human immunodeficiency virus type 1 infection and the development of AIDS in subjects with hemophilia. N Engl f Med 1989;321:1141-8.

14 European Collaborative Study. Mother-to-child transmission of HIV infection. Lancet 1988;ii:1039-43.

15 Blanche S, Rouzioux C, Moscato M-LG, et al. A prospective study of infant born to women seropositive for human immunodeficiency virus type N Engl F Med 1989;300:1643-8.

16 Auger I, Thomas P, de Gruttola V. Incubation periods for paediatric patients. Nature 1988;336:575-7.

17 Byers RH Jr, Morgan WM, Darrow WW, el al. Estimating AIDS infection rates in the San Francisco Cohort. AIDS 1988;2:207-10.
18 Darrow WW, Echenberg DF, Jaffe HW, et al. Risk factors for human immunodeficiency virus (HIV) infections in homosexual men. Am $\mathcal{J}$ Public Health 1987;77:479-83.

19 Hessol NA, Lifson AR, O'Malley PM, Doll LS, Jaffe HW, Rutherford GW Prevalence, incidence, and progression of human immunodeficiency virus infection in homosexual and bisexual men in hepatitis B vaccine trials, 19781988. Am f E pidemiol 1989;130:1167-75.

$20 \mathrm{Jaffe}$ HW, Darrow WW, Echenberg DF, et al. The acquired immunodeficiency syndrome in a cohort of homosexual and bisexual men: a six-year follow-up study. Ann Intern Med 1985;103:210-4.

21 Lui K-J, Darrow WW, Rutherford GW III. A model-based estimate of the mean incubation period for AIDS in homosexual men. Science 1988;240: 333-5.

22 Schreeder MT, Thompson SE, Hadler SC, et al. Hepatitis B in homosexua men: prevalence of infection and factors related to transmission. $\mathcal{F}$ Infect $D$ is 1982;146:7-25.

23 Francis DP, Hadler SC, Thompson SE, et al. The prevention of hepatitis B with vaccine: report of the Centers for Disease Control multi-center efficacy trial among homosexual men. Ann Intern Med 1982;97:362-6.

24 Centers for Disease Control. Pneumocystis pneumonia - Los Angeles. MMWR 1981;30:250-2.

25 Centers for Disease Control. Revision of the case definition for acquired immunodeficiency syndrome. $M M W R$ 1987;36 (suppl 2S):1-15.

26 Gallo D, Diggs JL, Shell GR, Daily PJ, Hoffman MN, Riggs JL. Comparison of detection of antibody to the acquired immune deficiency syndrome virus by enzyme immunoassay, immunofluorescence, and western blot methods. f Clin Microbiol 1986;23:1049-51.

27 Centers for Disease Control. Interpretation and use of the western blot assay for serodiagnosis of human immunodeficiency virus type 1 infections. MMWR 1989;38(suppl 7S):1-7.

28 SAS Institute. SAS User's Guide: Statistics. Version 5. Cary, North Carolina: SAS Institute, 1985.

29 Dixon WJ, ed. BMDP statistical sofrware. Los Angeles: University of California Press, 1985

30 Skolnik PR, Kosloff BR, Hirsch MS. Bidirectional interactions between human immunodeficiency virus type 1 and cytomegalovirus. $\mathcal{F}$ Infect Dis 1988;157: 508-14

31 Albrecht MA, Gillis JM, Adrea NT, Hammer SM. Human immunodeficiency virus (HIV) herpes simplex virus (HSV) interactions in vitro [Abstract 839] In: Program and abstracts of the 27 th interscience conference on antimicrobial agents and chemotherapy. Washington, DC: American Society for Microbiology, 1987:243.

32 Berger JR, McCarthy M, Resnick L, et al. History of syphilis as a cofactor for the expression of HIV infection [Abstract MAP 90]. In: Abstracts of the fifth international conference on AIDS. Montreal, Quebec: International Developinternational conference on AIDS. Montreal, Quebec: International Development Research Cent
isation, 1989:93.

33 Holton D, Cameron DW, Simonsen JN, Ndinya-Achola JO, Ngugi E, Plummer FA. Factors associated with HIV progression in Nairobi prostitute [Abstract MAP 110]. In: Abstracts of the fifth international conference on AIDS. Montreal, Quebec: International Development Research Centre, Health and Welfare Canada, World Health Organisation, 1989:96.

34 Kaslow RA, Van Raden M, DeLoria M, et al. Do clinical herpes simplex virus (HSV) and varicella-zoster virus (VZV) infections accelerate HIV-l-induced immunodeficiency? [Abstract ThAP 100]. In: Abstracts of the fifth international conference on AIDS. Montreal, Quebec: International Development Research Centre, Health and Welfare Canada, World Health Organisation, 1989:157.

35 Biggar RJ, Seroconverters Working Group. Time-to-AIDS among 816 seroconverters [Abstract ThAO 22]. In: Abstracts of the fifth international conference on AIDS. Montreal, Quebec: International Development Research conference on AIDS. Montreal, Quebec: International Development Research

36 Hessol NA, Lifson AR. Predictors of HIV disease progression In: Volberding PA, Jacobson MA, ed. 1990 AIDS clinical review. New York: Marcel PA, Jacobson MA,

37 Anzala $A$, Wambugu P, Bosire $M$, Ngugi EN, Waiyaki P, Plummer FA. The rate of development of HIV-1 related illness in women with a known duration of infection [Abstract ThC 37]. In: Final program and abstracts of the sixth international conference on AIDS. Vol 1. San Francisco, California University of California San Francisco, World Health Organisation, City and County of San Francisco, American Foundation for AIDS Research, International AIDS Society, 1990:143.

38 Royce R, Winkelstein W, Bacchetti P. Cigarette smoking and incidence of AIDS [Abstract ThC 39]. In: Final program and abstracts of the sixth international conference on AIDS. Vol 1. San Francisco, California: University of California San Francisco, World Health Organisation, City and County of San Francisco, American Foundation for AIDS Research, International AIDS Society, 1990:143.

39 Park LP, Munoz A, Armenian H, et al. Interaction between HIV-1 infection and smoking on CD4 lymphocyte count [Abstract ThC 675]. In: Final
program and abstracts of the sixth international conference on AIDS. Vol 1 . San program and abstracts of the sixth international conference on AIDS. Vol 1. San Francisco, California: University of California San Francisco, World Health Organisation, City and County of San Francisco, American

40 Weber R, Ledergerber B, Opravil M, Luthy R. Cessation of intravenous drug use reduces progression of HIV-infection in HIV + drug users. [Abstract ThC 36]. In: Final program and abstracts of the sixth intermational conference on AIDS. Vol 1. San Francisco, California: University of California San Francisco, World Health Organisation, City and County of San Francisco, American Foundation for AIDS Research, International AIDS Society, 1990:142.

41 Berrebi A, Puel J, Tricoire J, Herne H, Pontonnier G. Influence of gestation on HIV infection [Abstract ThC 651]. In: Final program and abstracts of the sixth international conference on AIDS. Vol 1. San Francisco, California: University of California San Francisco, World Health Organsation, City and County of of California San Francisco, World Health Organsation, City and County of San Francisco, American
AIDS Society, 1990:287.

42 Bledsoe K, Olopoenia L, Barnes S, Delapenha R, Saxinger C, Frederick W. Effect of pregnancy of progression of HIV infection [Abstract ThC 652]. In: Final program and abstracts of the sixth intermational conference on AIDS. Vo 1. San Francisco, California: University of California San Francisco, World Health Organisation, City and County of San Francisco, American Foun dation for AIDS Research, International AIDS Society, 1990:288

43 Kemeny ME, Duran R, Taylor SE, Weiner H, Visscher B, Fahey JL. Chronic depression predicts CD4 decline over a five year period in HIV seropositive men [Abstract $\mathrm{ThC}$ 678]. In: Final program and abstracts of the sixth international conference on AIDS. Vol 1. San Francisco, California: University 
of California San Francisco, World Health Organisation, City and County of San Francisco, American Foundation for AIDS Research, International AIDS Society, 1990:295.

44 Steel CM, Ludlam CA, Beatson D, et al. HLA haplotype Al B8 DR3 as a risk factor for HIV-related disease. Lancet 1988;i:1185-8.

45 Mann DL, Murray C, Yarchoan R, Blattner WA, Goeddert JJ. HLA antigen frequencies in HIV-I seropositive disease-free individuals and patients with AIDS fournal of AIDS 1988:1:13-7.

46 Ranki A, Valle SL, Krohn M, et al. Long latency precedes overt seroconversion in sexually transmitted human immunodeficiency virus infection. Lancet 1987; ii: 589-93.

47 Wolinsky SM, Rinaldo CR, Kwok S, et al. Human immunodeficiency virus type 1 (HIV-1) infection a median of 18 months before a diagnostic western blot: evidence from a cohort of homosexual men. Ann Intern Med 1989;111 $961-72$
48 Imagawa DT, Lee MH, Wolinsky SM, et al. Human immunodeficiency virus type 1 infection in homosexual men who remain seronegative for prolonged periods. N Engl f Med 1989;321:1458-62.

49 Horsburgh CR, Ou CY, Holmberg SD, et al. Human immunodeficiency virus type 1 infection in homosexual men who remain seronegative for prolonged

50 Lifson AR, Stanley M, Pane J, et al. Detection of human imunodeficiency virus DNA using the polymerase chain reaction in a well characterized group of homosexual and bisexual men. F Infect Dis 1990;161:436-9.

51 Horsburgh CR, Ou Cy, Jason J, et al. Duration of human immunodeficiency virus infection before detection of antibody. Lancet 1989;ii:637-40.

52 Volberding PA, Lagakos SW, Koch MA, et al. Zidovudine in asymptomatic human immunodeficiency virus infection. $N$ Engl f Med 1990;322:941-9.

(Accepted 22 October 1990)

\title{
Diagnosis of abdominal masses with percutaneous biopsy guided by ultrasound
}

\author{
H J Jaeger, J MacFie, C J Mitchell, N Couse, D Wai
}

\section{Abstract}

Objective-To assess the accuracy and safety of percutaneous biopsy of abdominal masses guided by ultrasound.

Design-Prospective study.

Setting-Combined gastroenterology service, Scarborough Hospital.

Patients - 108 Consecutive patients identified as having a discrete mass on diagnostic ultrasound examination of the abdomen.

Intervention-A sample of tissue was obtained with an aseptic technique under local anaesthesia: an 18 steel wire gauge needle (Tru-Cut) was mounted in a spring loaded firing device (Biopty gun) that was advanced under simultaneous ultrasound scanning, permitting precise localisation of the target organ.

Main outcome measure-Results of histological examination of tissue specimens.

Results-Biopsy failed in four patients. Adequate histological specimens were obtained in 104 patients with masses in the liver (31), pancreas (37), kidney (10), and adrenal glands (six) and in 20 undiagnosed abdominal and retroperitoneal masses. Follow up was until death or confirmation of the diagnosis. Three complications but no deaths occurred. Malignancy was suspected in 84 patients before biopsy. This was confirmed in 70 patients, in 26 of whom confirmation of dissemination obviated the need for further investigation. In 10 patients biopsy indicated a previously unsuspected primary tumour, and in $\mathbf{1 2}$ it showed only a benign lesion. Among 24 patients considered to have benign disease biopsy showed an unsuspected neoplasm in seven. Use of biopsy thus had a major effect on clinical management in 55 patients. Four false negative but no false positive diagnoses resulted from the procedure.

Conclusion-Percutaneous biopsy of abdominal and retroperitoneal masses under ultrasound guidance is a safe and accurate method of obtaining a histological diagnosis. The results obtained have a considerable effect on clinical management.

H J Jaeger, $\mathrm{MB}$, senior house officer in general surgery

$\mathrm{J}$ MacFie, FRCs, consultant surgeon

C J Mitchell, FRCP, consultant physician

N Couse, FRCSI, surgical registrar

D Wai, FRCR, consultant radiologist

Correspondence to:

Dr Mitchell. nancy, in whom surgery is often hazardous. Attempts to overcome this problem with percutaneous biopsies with large gauge needles have had only limited success

An important obstacle in managing patients with difficulty in safely obtaining an accurate diagnosis on the results of histological examin without doing a laparotomy. This is particularly important in elderly patients with suspected malig- because of considerable associated morbidity. ${ }^{12}$ Many authors recommend using fine needle aspiration cytology, but this requires specialist skills, which are not always available. ${ }^{3-7}$

More recently a system has been developed that enables biopsy of the targeted organ to be performed percutaneously with ultrasound guidance. ${ }^{8}$ The tissue specimens obtained are suitable for routine histological examination. After successfully applying this technique to biopsy of the pancreas ${ }^{9}$ we applied it more generally in investigating patients with abdominal masses. We report our initial experience with particular reference to the accuracy and safety of the technique.

\section{Patients and methods}

We analysed prospectively 108 consecutive patients who presented to our combined gastroenterology service over three years in whom abdominal ultrasound scanning confirmed the presence of a clinically or radiologically suspected mass or identified a previously undetected discrete mass. In many cases malignancy was suspected and it was important to confirm or exclude the presence of disseminated disease. Thirty two patients underwent percutaneous biopsy, guided by ultrasound, of lesions of the liver. In 13 patients with hepatomegaly ultrasound scanning showed single (seven) or multiple (six) lesions. Eleven patients with proved malignant disease were scanned to exclude liver metastases. In eight patients ultrasound scanning was performed to investigate non-specific abdominal symptoms.

Twenty patients underwent biopsy of abdominal or retroperitoneal lesions. Six had a palpable abdominal mass, and two presented with abdominal pain but had no abnormalities on examination or on contrast radiological examination. Six patients underwent biopsy of para-aortic or retroperitoneal lymph nodes, of whom two had received treatment for lymphoma. Three patients with abnormal results of liver function tests had portal lymphadenopathy on ultrasound examination. Two patients underwent biopsy of the pylorus after equivocal findings on endoscopy and radiological examination. One patient in whom the result of endoscopic retrograde cholangiopancreatography was equivocal had a lesion identified in the choledochojejunal anastomosis from a previous Whipple's operation. All but six of this group had other extensive investigations before ultrasound scanning identified a mass.

Ten patients underwent biopsy of renal masses; in six these were an incidental finding at intravenous urography. Two patients had had a nephrectomy for 